\title{
ON POST QUANTUM INTEGRAL INEQUALITIES
}

\author{
Muhammad Uzair Awan, Sadia Talib, Muhammad Aslam Noor, \\ KHALIDA INAYAT NOOR AND YU-MING CHU*
}

\begin{abstract}
In the article, we provide some new post quantum refinements of the Hermite-Hadamard like inequalities involving the class of $\mathrm{h}$-preinvex functions by establishing a new auxiliary result involving the post quantum differentiable function. By discussing some special cases, it is shown that our obtained results are the further generalizations of many previous known results.
\end{abstract}

Mathematics subject classification (2020): 26A51, 26D15, 05A30.

Keywords and phrases: Convexity, preinvexity, quantum calculus, Hermite-Hadamard inequality.

\section{REFERENCES}

[1] I. Abbas Baloch And Y.-M. Chu, Petrović-type inequalities for harmonic $h$-convex functions, J. Funct. Spaces, 2020 (2020), Article ID 3075390, 7 pages.

[2] T. Abdeluawad, S. Rashid, H. Khan AND Y.-M. ChU, On new fractional integral inequalities for p-convexity within interval-valued functions, Adv. Difference Equ., 2020 (2020), Article 330, 17 pages.

[3] M. Adil Khan, Y.-M. Chu, A. Kashuri, R. Liko And G. Ali, Conformable fractional integrals versions of Hermite-Hadamard inequalities and their generalizations, J. Funct. Spaces, 2018 (2018), Article ID 6928130, 9 pages.

[4] M. Adil Khan, Y.-M. Chu, T. U. Khan and J. Khan, Some new inequalities of HermiteHadamard type for s-convex functions with applications, Open Math., 15, 1 (2017), 1414-1430.

[5] M. Adil Khan, M. Hanif, Z. A. Khan, K. Ahmad and Y.-M. Chu, Association of Jensen's inequality for s-convex function with Csiszár divergence, J. Inequal. Appl., 2019 (2019), Article 162, 14 pages.

[6] M. Adil Khan, A. IQbal, M. Suleman And Y.-M. Chu, Hermite-Hadamard type inequalities for fractional integrals via Green's function, J. Inequal. Appl., 2018 (2018), Article 161, 15 pages.

[7] M. Adil Khan, Y. Khurshid, T.-S. Du AND Y.-M. ChU, Generalization of Hermite-Hadamard type inequalities via conformable fractional integrals, J. Funct. Spaces, 2018 (2018), Article ID 5357463, 12 pages.

[8] M. Adil Khan, N. Mohammad, E. R. Nwaeze and Y.-M. Chu, Quantum Hermite-Hadamard inequality by means of a Green function, Adv. Difference Equ., 2020 (2020), Article 99, 20 pages.

[9] M. AdIL KHAN, J. PEČARIĆ AND Y.-M. CHU, Refinements of Jensen's and McShane's inequalities with applications, AIMS Math., 5, 5 (2020), 4931-4945.

[10] M. Adil Khan, S.-H. Wu, H. Ullah AND Y.-M. ChU, Discrete majorization type inequalities for convex functions on rectangles, J. Inequal. Appl., 2019 (2019), Article 16, 18 pages.

[11] M. Adil Khan, S. Zaheer Ullah AND Y.-M. ChU, The concept of coordinate strongly convex functions and related inequalities, Rev. R. Acad. Cienc. Exactas Fís. Nat. Ser. A Mat., 113, 3 (2019), 2235-2251.

[12] P. Agarwal, M. Kadakal, İ. İşCan And Y.-M. ChU, Better approaches for $n$-times differentiable convex functions, Mathematics, 8, 6 (2020), Article ID 950, 11 pages.

[13] R. Anjum, S. Ullah, Y.-M. Chu, M. Munir, N. Kausar And S. Kadry, Characterizations of ordered h-regular semirings by ordered h-ideals, AIMS Math., 5, 6 (2020), 5768-5790.

[14] M. U. Awan, N. Akhtar, A. Kashuri, M. A. Noor And Y.-M. ChU, $2 D$ approximately reciprocal $\rho$-convex functions and associated integral inequalities, AIMS Math., 5, 5 (2020), 4662-4680. 
[15] M. U. Awan, N. Akhtar, S. Iftikhar, M. A. Noor And Y.-M. ChU, New Hermite-Hadamard type inequalities for n-polynomial harmonically convex functions, J. Inequal. Appl., 2020 (2020), Article 125, 12 pages.

[16] M. U. Awan, S. TAlib, Y.-M. Chu, M. A. Noor And K. I. Noor, Some new refinements of Hermite-Hadamard-type inequalities involving $\Psi_{k}$-Riemann-Liouville fractional integrals and applications, Math. Probl. Eng., 2020 (2020), Article ID 3051920, 10 pages.

[17] Y.-M. Chu, M. Adil Khan, T. Ali AND S. S. Dragomir, Inequalities for $\alpha$-fractional differentiable functions, J. Inequal. Appl., 2017 (2017), Article 93, 12 pages.

[18] Y.-M. ChU, Y.-F. QIU AND M.-K. WANG, Hölder mean inequalities for the complete elliptic integrals, Integral Transforms Spec. Funct., 23, 7 (2012), 521-527.

[19] Y.-M. ChU, M.-K. WANG, Y.-P. JiAng AND S.-L. QIU, Concavity of the complete elliptic integrals of the second kind with respect to Hölder means, J. Math. Anal. Appl., 395, 2 (2012), 637-642.

[20] Y.-M. ChU, G.-D. WANG AND X.-H. ZHANG, The Schur multiplicative and harmonic convexities of the complete symmetric function, Math. Nachr., 284, 5-6 (2011), 653-663.

[21] Y.-M. ChU, W.-F. XIA AND X.-H. ZHANG, The Schur concavity, Schur multiplicative and harmonic convexities of the second dual form of the Hamy symmetric function with applications, J. Multivariate Anal., 105 (2012), 412-421.

[22] H. Ge-Ji Le, S. Rashid, M. A. Noor, A. Suhail and Y.-M. Chu, Some unified bounds for exponentially tgs-convex functions governed by conformable fractional operators, AIMS Math., 5, 6 (2020), 6108-6123.

[23] X.-M. Hu, J.-F. Tian, Y.-M. Chu And Y.-X. Lu, On Cauchy-Schwarz inequality for N-tuple diamond-alpha integral, J. Inequal. Appl., 2020 (2020), Article 18, 15 pages.

[24] T.-R. HuAnG, B.-W. HAN, X.-Y. MA AND Y.-M. ChU, Optimal bounds for the generalized EulerMascheroni constant, J. Inequal. Appl., 2018 (2018), Article 118, 9 pages.

[25] T.-R. HuAnG, S.-Y. TAN, X.-Y. MA AND Y.-M. ChU, Monotonicity properties and bounds for the complete p-elliptic integrals, J. Inequal. Appl., 2018 (2018), Article 239, 11 pages.

[26] S. Hussain, J. Khalid And Y.-M. Chu, Some generalized fractional integral Simpson's type inequalities with applications, AIMS Math., 5, 6 (2020), 5859-5883.

[27] A. Iqbal, M. Adil Khan, N. Mohammad, E. R. Nwaeze and Y.-M. Chu, Revisiting the Hermite-Hadamard integral inequality via a Green function, AIMS Math., 5, 6 (2020), 6087-6107.

[28] A. IQbal, M. Adil Khan, S. Ullah and Y.-M. ChU, Some new Hermite-Hadamard-type inequalities associated with conformable fractional integrals and their applications, J. Funct. Spaces, 2020 (2020), Article ID 9845407, 18 pages.

[29] H. Kalsoom, M. IdReES, D. Baleanu AND Y.-M. ChU, New estimates of $q_{1} q_{2}$-Ostrowski-type inequalities with a class of n-polynomial prevexity of function, J. Funct. Spaces, 2020 (2020), Article ID 3720798, 13 pages.

[30] S. Khan, M. Adil Khan And Y.-M. Chu, Converses of the Jensen inequality derived from the Green functions with applications in information theory, Math. Methods Appl. Sci., 43, 5 (2020), 2577-2587.

[31] Y. Khurshid, M. Adil Khan And Y.-M. Chu, Conformable integral inequalities of the HermiteHadamard type in terms of GG- and GA-convexities, J. Funct. Spaces, 2019 (2019), Article ID 6926107, 8 pages.

[32] Y. Khurshid, M. Adil Khan And Y.-M. Chu, Conformable fractional integral inequalities for $G G$ - and GA-convex function, AIMS Math., 5, 5 (2020), 5012-5030.

[33] Y. Khurshid, M. Adil Khan And Y.-M. ChU, Conformable integral version of HermiteHadamard-Fejér inequalities via $\eta$-convex functions, AIMS Math., 5, 5 (2020), 5106-5120.

[34] Y. Khurshid, M. Adil Khan, Y.-M. Chu And Z. A. Khan, Hermite-Hadamard-Fejér inequalities for conformable fractional integrals via preinvex functions, J. Funct. Spaces, 2019 (2019), Article ID 3146210, 9 pages.

[35] M. A. Latif, S. Rashid, S. S. Dragomir And Y.-M. Chu, Hermite-Hadamard type inequalities for co-ordinated convex and qausi-convex functions and their applications, J. Inequal. Appl., 2019 (2019), Article 317, 33 pages.

[36] C. LuO, T. S. Du, M. U. AwAN AND Y. Zhang, Estimation-type results with respect to the parameterized $(p, q)$-integral inequalities, AIMS Math., 5, 1 (2019), 568-586.

[37] X.-Q. Ma, U. Muhammad Awais, S. Nazeer, Y.-M. Chu and Y.-Y. LiU, Stacked book graphs are cycle-antimagic, AIMS Math., 5, 6 (2020), 6043-6050. 
[38] M. A. Noor, K. I. Noor, M. U. Awan And J. Li, On Hermite-Hadamard inequalities for $h$ preinvex functions, Filomat, 28, 7 (2014), 1463-1474.

[39] S. QAyyum, M. IJaz Khan, F. Masood, Y.-M. Chu, S. KadRy And M. NazeEr, Interpretation of entropy generation in Williamson fluid flow with nonlinear thermal radiation and first-order velocity slip, Math. Methods Appl. Sci., doi:10.1002//mma.6735.

[40] H.-X. QI, M. Yussouf, S. Mehmood, Y.-M. ChU AND G. FARID, Fractional integral versions of Hermite-Hadamard type inequality for generalized exponentially convexity, AIMS Math., 5, 6 (2020), 6030-6042.

[41] W.-M. Qian, Z.-Y. HE AND Y.-M. CHU, Approximation for the complete elliptic integral of the first kind, Rev. R. Acad. Cienc. Exactas Fís. Nat. Ser. A Mat., 114, 2 (2020), Article 57, 12 pages, https://doi.org/10.1007/s13398-020-00784-9.

[42] W.-M. QIAN, Z.-Y. HE, H.-W. ZHANG AND Y.-M. CHU, Sharp bounds for Neuman means in terms of two-parameter contraharmonic and arithmetic mean, J. Inequal. Appl., 2019 (2019), Articel 168, 13 pages.

[43] W.-M. QiAn, Y.-Y. YANG, H.-W. Zhang AND Y.-M. CHU, Optimal two-parameter geometric and arithmetic mean bounds for the Sándor-Yang mean, J. Inequal. Appl., 2019 (2019), Articel 287, 12 pages.

[44] W.-M. QIAN, W. ZHANG AND Y.-M. CHU, Bounding the convex combination of arithmetic and integral means in terms of one-parameter harmonic and geometric means, Miskolc Math. Notes, 20, 2 (2019), 1157-1166.

[45] S.-L. QIU, X.-Y. MA AND Y.-M. CHU, Sharp Landen transformation inequalities for hypergeometric functions, with applications, J. Math. Anal. Appl., 474, 2 (2019), 1306-1337.

[46] S. Rafeeq, H. Kalsoom, S. Hussain, S. Rashid And Y.-M. CHu, Delay dynamic double integral inequalities on time scales with applications, Adv. Difference Equ., 2020 (2020), Article 40, 32 pages.

[47] S. Rashid, R. Ashraf, M. A. Noor, K. I. Noor And Y.-M. CHU, New weighted generalizations for differentiable exponentially convex mapping with application, AIMS Math., 5, 6 (2020), 35253546.

[48] S. Rashid, Z. Hammouch, D. Baleanu and Y.-M. Chu, New generalizations in the sense of the weighted non-singular fractional integral operator, Fractals, 28, 7 (2020), Article ID 2040003, 11 pages. https://dx.doi.org/10.1142/S0218348X20400034

[49] S. RAShid, Z. HAMmouCH, F. JARAD AND Y.-M. CHU, New estimates of integral inequalities via generalized proportional fractional integral operator with respect to another function, Fractals, 28, 8 (2020), Article ID 2040027, 12 pages, https://dx. doi.org/10.1142/S0218348X20400277.

[50] S. RASHID, İ. İşCAN, D. BALEANU AND Y.-M. CHU, Generation of new fractional inequalities via $n$ polynomials s-type convexixity with applications, Adv. Difference Equ., 2020 (2020), Article 264, 20 pages.

[51] S. RAShid, F. JARAD AND Y.-M. CHU, A note on reverse Minkowski inequality via generalized proportional fractional integral operator with respect to another function, Math. Probl. Eng., 2020 (2020), Article ID 7630260, 12 pages.

[52] S. Rashid, F. Jarad, H. Kalsoom And Y.-M. Chu, On Pólya-Szegö and Ćebyšev type inequalities via generalized $k$-fractional integrals, Adv. Difference Equ., 2020 (2020), Article 125, 18 pages.

[53] S. Rashid, F. JARAd, M. A. Noor, H. Kalsoom And Y.-M. CHU, Inequalities by means of generalized proportional fractional integral operators with respect to another function, Mathematics, 7, 12 (2019), Article ID 1225, 18 pages.

[54] S. Rashid, A. Khalid, G. Rahman,, K. S. Nisar And Y.-M. CHU, On new modifications governed by quantum Hahn's integral operator pertaining to fractional calculus, J. Funct. Spaces, 2020 (2020), Article ID 8262860, 12 pages.

[55] S. Rashid, M. A. Noor, K. I. Noor And Y.-M. Chu, Ostrowski type inequalities in the sense of generalized $\mathscr{K}$-fractional integral operator for exponentially convex functions, AIMS Math., 5, 3 (2020), 2629-2645.

[56] S. Rashid, M. A. Noor, K. I. Noor, F. Safdar And Y.-M. Chu, Hermite-Hadamrad type inequalities for the class of convex functions on time scale, Mathematics, 7, 10 (2019), Article ID 956, 20 pages.

[57] J.-M. Shen, S. RAshid, M. A. Noor, R. Ashraf And Y.-M. CHU, Certain novel estimates within fractional calculus theory on time scales, AIMS Math., 5, 6 (2020), 6073-6086. 
[58] J.-M. Shen, Z.-H. YAng, W.-M. QIAN, W. Zhang AND Y.-M. ChU, Sharp rational bounds for gamma function, Math. Inequal. Appl., 23, 3 (2020), 843-853.

[59] Y.-Q. Song, M. Adil Khan, S. Zaheer Ullah And Y.-M. ChU, Integral inequalities involving strongly convex functions, J. Funct. Spaces, 2018 (2018), Article ID 6595921, 8 pages.

[60] M.-B. SUN AND Y.-M. CHU, Inequalities for the generalized weighted mean values of $g$-onvex functions with applications, Rev. R. Acad. Cienc. Exactas Fís. Nat. Ser. A Mat., 114, 4 (2020), Article 172, 12 pages, https://doi.org/10.1007/s13398-020-00908-1.

[61] J. TARIBOON AND S. K. NTOUYAS, Quantum integral inequalities on finite intervals, J. Inequal. Appl., 2019 (2019), Article 121, 13 pages.

[62] M. Tunç AND E. Göv, Some integral inequalities via $(p, q)$-calculus on finite intervals, RGMIA Res. Rep. Coll., 19 (2016), Aritcle 56, 12 pages.

[63] S. VARoŠAnec, On h-convexity, J. Math. Anal. Appl., 326, 1 (2007), 303-311.

[64] M.-K. WANG AND Y.-M. CHU, Refinements of transformation inequalities for zero-balanced hypergeometric functions, Acta Math. Sci., 37B, 3 (2017), 607-622.

[65] M.-K. WANG AND Y.-M. CHU, Landen inequalities for a class of hypergeometric functions with applications, Math. Inequal. Appl., 21, 2 (2018), 521-537.

[66] M.-K. WAng, H.-H. Chu And Y.-M. ChU, Precise bounds for the weighted Hölder mean of the complete p-elliptic integrals, J. Math. Anal. Appl., 480, 2 (2019), Article ID 123388, 9 pages, https://doi.org/10.1016/j.jmaa.2019.123388.

[67] M.-K. WANG, Y.-M. CHU AND Y.-P. JIANG, Ramanujan's cubic transformation inequalities for zero-balanced hypergeometric functions, Rocky Mountain J. Math., 46, 2 (2016), 679-691.

[68] M.-K. WANG, H.-H. ChU, Y.-M. LI AND Y.-M. CHU, Answers to three conjectures on convexity of three functions involving complete elliptic integrals of the first kind, Appl. Anal. Discrete Math., 14 (2020), 255-271.

[69] M.-K. WANG, Y.-M. ChU, Y.-M. Li AND W. ZHANG, Asymptotic expansion and bounds for complete elliptic integrals, Math. Inequal. Appl., 23, 3 (2020), 821-841.

[70] M.-K. WANG, Y.-M. ChU, S.-L. QIU AND Y.-P. JIANG, Bounds for the perimeter of an ellipse, J. Approx. Theory, 164, 7 (2012), 928-937.

[71] M.-K. WANG, Z.-Y. HE AND Y.-M. CHU, Sharp power mean inequalities for the generalized elliptic integral of the first kind, Comput. Methods Funct. Theory, 20, 1 (2020), 111-124.

[72] M.-K. WANG, M.-Y. Hong, Y.-F. XU, Z.-H. Shen AND Y.-M. CHU, Inequalities for generalized trigonometric and hyperbolic functions with one parameter, J. Math. Inequal., 14, 1 (2020), 1-21.

[73] B. WANG, C.-L. LuO, S.-H. Li AND Y.-M. CHU, Sharp one-parameter geometric and quadratic means bounds for the Sándor-Yang means, Rev. R. Acad. Cienc. Exactas Fís. Nat. Ser. A Mat., 114, 1 (2020), Article 7, 10 pages, https://doi .org/10.1007/s13398-019-00734-0.

[74] T. Weir And B. Mond, Pre-invex functions in multiple objective optimization, J. Math. Anal. Appl., 136, 1 (1988), 29-38.

[75] L. XU, Y.-M. ChU, S. Rashid, A. A. El-Deeb AND K. S. Nisar, On new unified bounds for a family of functions with fractional q-calculus theory, J. Funct. Spaces, 2020 (2020), Article ID 4984612, 9 pages.

[76] Z.-H. YANG, W.-M. QiAn, W. Zhang AND Y.-M. CHU, Notes on the complete elliptic integral of the first kind, Math. Inequal. Appl., 23, 1 (2020), 77-93.

[77] S. Zaheer Ullah, M. Adil Khan and Y.-M. ChU, Majorization theorems for strongly convex functions, J. Inequal. Appl., 2019 (2019), Article 58, 13 pages.

[78] S. Zaheer Ullah, M. Adil Khan And Y.-M. ChU, A note on generalized convex functions, J. Inequal. Appl., 2019 (2019), Article 291, 10 pages.

[79] S. Zaheer Ullah, M. Adil Khan, Z. A. Khan and Y.-M. Chu, Integral majorization type inequalities for the functions in the sense of strong convexity, J. Funct. Spaces, 2019 (2019), Article ID 9487823,11 pages.

[80] T.-H.ZHAO, Y.-M. CHU AND H. WANG, Logarithmically complete monotonicity properties relating to the gamma function, Abstr. Appl. Anal., 2011 (2011), Article ID 896483, 13 pages.

[81] T.-H. Zhao, L. Shi AND Y.-M. ChU, Convexity and concavity of the modified Bessel functions of the first kind with respect to Hölder means, Rev. R. Acad. Cienc. Exactas Fís. Nat. Ser. A Mat., 114, 2 (2020), Article 96, 14 pages, https://doi.org/10.1007/s13398-020-00825-3.

[82] T.-H. ZhaO, M.-K. WANG AND Y.-M. CHU, A sharp double inequality involving generalized complete elliptic integral of the first kind, AIMS Math., 5, 5 (2010), 4512-4528. 
[83] S.-S. Zhou, S. RASHid, F. JARAd, H. Kalsoom And Y.-M. ChU, New estimates considering the generalized proportional Hadamard fractional integral operators, Adv. Difference Equ., 2020 (2020), Article 275, 15 pages. 